\title{
Civilians in Defense Ministries
}

\section{Todor Tagarev ${ }^{*}$}

It is a truism to say that healthy civil-military relations are indispensable for keeping defense establishments accountable to society. In addition, there is a growing understanding that smooth interaction between civilians and the military is key if we wish to keep the armed forces effective in implementing a country's security and defense policy within limited budgets.

It is clear who the military are: men and women at arms ready to protect the nation and its allies from risks and threats of organized violence that may originate close to or very far away from the territory of their own country or the territory of allies. But what is the meaning of civilian, or defense civilian, in discussing civil-military relations?

This essay examines the issue of civilians in a defense establishment. First, it presents the factors that drive the involvement of civilians in defense and points out some common perceptions, or rather misperceptions, in Central and Eastern European countries. Next, it offers a classification of civilian personnel in defense. Then it examines the profession of "defense civilian" vis-à-vis the military profession. Finally, it presents a few ideas that, if properly implemented, will contribute to the establishment of a professional corps of civilian defense experts.

\section{Civilians in Defense}

There are two principal drivers for having civilians working within a defense establishment. The first is to ensure democratic control over defense and armed forces; the second aims to increase effectiveness in the use of limited resources, both human and financial. A great deal has been written in regard to the first of these drivers. Often, even the term "democratic control" of the armed forces is equated with the term "civilian control." The role of parliaments, media scrutiny, interactions with NGOs, and relations with society are treated under the motto of "civilian control" or "democratic civil-military relations." As a rule, democratic countries add to this understanding of

\footnotetext{
Dr. Todor Tagarev is associate professor and Chair of the Defense and Force Management Department at the "G.S. Rakovski" Defense and Staff College in Sofia, Bulgaria. A civilian, in 1999 he became the first Director of the Defense Planning Directorate of Bulgaria's Ministry of Defense. He performed this function until 2001, working during a decisive phase of planning and implementing defense reforms to prepare the armed forces for the country's integration into NATO. This paper was originally prepared for a workshop of the PfP Consortium's Security Sector Reform Working Group. The author's participation in the workshop was supported by the Geneva Centre for the Democratic Control of Armed Forces (DCAF).
} 
civilian control the element of executive oversight exercised by a civilian minister or secretary of defense and his or her "political cabinet."

In modern states, institutions possessing the means to apply force (including the military) are separate from institutions that decide about the allocation of public resources (political parties, legislatures, presidencies). ${ }^{2}$ Military officers readily recognize the supremacy of civilians - elected within the framework of a democratic process - in setting security and defense policies and defining the missions and the tasks of the armed forces. But often, particularly in post-Soviet countries and other former members of the Warsaw Pact, the understanding of how civilian control of the armed forces works is that elected officials set policy objectives and issue guidance, the military experts (through their highest authority, the General Staff) assess what means (forces) are needed in order to implement the policy, and the legislative and executive branches of government provide the necessary resources.

This concept is clear, simple, and wrong. It is wrong because defense policy is not defined in a void; part of the process of elaborating defense policy is the formulation of a strategy, including a strategy for the contribution to be made by the armed forces to the achievement of national security objectives. Also, every "defense policy" becomes a policy only when it is realistic - that is, when decision makers in parliament and in the executive are fairly confident that the means and resources needed to implement the policy would be available. In other words, there are no clear boundaries between "political decision making" and "military expertise" in defining what armed forces a country needs and how, strategically, to use them.

Furthermore, modern leadership and management theories very clearly define the need to make the most of diverse expertise and advice in making strategic decisions. When the future of an organization is at stake, the leader should actively seek alternative viewpoints, rationales, and proposals. The opportunities to seek alternative opinions in a strictly hierarchical system, such as armed forces subordinated to a General Staff, are very limited. Therefore, if a defense minister wants alternative advice, he or she needs to establish or have two key elements in place: a decision-making process that cuts across organizational levels, and a variety of experts that are able, allowed,

1 Of particular importance for establishing democratic control of the armed forces is the role of the head of state, e.g., the president, as supreme commander of the armed forces. This topic, however, is not discussed in this paper. Interested readers may refer to Chapter 3 in Hans Born, Philipp Fluri, and Andreas Johnsson, eds., Parliamentary Oversight of the Security Sector: Principles, Mechanisms, and Practices (Geneva: Geneva Centre for the Democratic Control of Armed Forces and the Inter-Parliamentary Union, 2003); and Valeri Ratchev, Chapter 5 in Civil-Military Relations and Democratic Control of the Security Sector, ed. Plamen Pantev (Sofia: Rakovski Defense and Staff College, 2005).

2 Daniel N. Nelson, "Civilians, The Military and Defense Planning in South East Europe: An Analysis of the Stability Pact Self-Assessment Studies," Chapter 9 in Defense and Security Sector Governance and Reform in South East Europe Self-Assessment Studies: Regional Perspectives, eds. Eden Cole, Timothy Donais and Philipp H. Fluri (Baden-Baden: Nomos Verlagsgesellschaft, November 2004), 125-35; available at www.dcaf.ch/publications/epublications/Defense_SSG_SSE/D_18.pdf. Quoted text at 126. 
and encouraged to put forward qualitatively different proposals. An expert civilian cadre (under certain conditions that will be described below) may be the source of such alternative proposals and advice.

The second driving factor is the need to make the most effective use of limited resources, including personnel and money. During the era of the Warsaw Pact, almost anyone who played a role in the defense establishment wore a uniform: an engineer in a military factory, a scientist in a research institute, a doctor in the garrison hospital, etc. In an era of preparation for a total war, that might have been logical. Today, however, it is usually clear who among the members of the defense establishment is expected to participate in combat or peacekeeping operations (and thus bears higher levels of personal risk) and who is not. ${ }^{3}$

It also clear that a civilian employed in the defense establishment costs less than a military officer. Only accounting for salaries and additional allowances, the employment of a civilian draws between a half and a third as much money from the defense budget as having an active duty officer or a senior NCO. ${ }^{4}$ Thus, just the need to use the defense budget efficiently drives the increase of civilian assignments to all positions in the defense establishment and the armed forces that do not require specific military expertise and do not involve professional military risks.

A later section of the essay presents the specific aspects of military expertise, and the military profession in general, that make it distinct from other occupations. But before that, I will revisit the question of exactly who are the civilians in a defense establishment.

\section{Categories of Civilians in Defense}

There are three general categories of civilians in defense:

1. Civilians who represent the political will of the governing party or coalition; these would include ministers, deputy/vice ministers, advisors and other members of the "political cabinet" of a ministry of defense ${ }^{5}$

2. Civilians that bring particular expertise in areas of close interaction with military expertise, such as policy makers, planners, contract managers, project managers, lawyers, etc. ${ }^{6}$

3 Barring the highly unlikely (according to current assessments) event of organized state aggression against the territory of the country, in which case often every citizen is obliged to serve under arms or to contribute to the defense of the country in other ways.

4 This takes into account such costs as social insurance, etc., but does not include military training.

5 Some countries have additional senior executive bodies, going by names like the "National Security Council" or "National Defense Council." Political appointees to such organizations are to be considered in this category of civilians, while the assigned experts may be seen as part of the next category of civilian defense personnel.

6 Some of these civilians are in leadership or senior management positions. For the purposes of this study, however, they will be considered as senior experts. 
3. Civilians in supporting functions, such as administrative support, management information systems support, non-combat communications, accounting, library and documentation services, engineering, maintenance and other technical services, catering, etc.

The main distinction between these civilians vis-à-vis the military is that none of these categories of personnel is expected to be employed in combat.

The ensuing discussion in this essay is focused on the second category of civilian personnel, which, in my opinion, not only brings the greatest increases in efficiency and effectiveness, but is indispensable in the establishment of sound democratic control over the armed forces. Therefore, the role of such civilians needs to be institutionalized. The highest degree of institutionalization is the formation of a distinct professional group: the profession of defense civilians, or civil servants, comprising categories 2 and 3 in the proposed classification above. But can we expect the formation of a distinct professional group of defense civilians? Should it, in fact, be distinct? Judging by the experience of Western democracies, the answer is "yes." The hypothesis of the existence of the profession of "defense civilian" will be tested against the characteristics of the military profession as distinct from other professions.

\section{The Military Profession}

Samuel Huntington, in his seminal work The Soldier and the State, which was first published half a century ago, outlined three distinguishing characteristics of the military profession: ${ }^{7}$

- Expertise in the application of violence (for the soldiers) and the management of violence (for the officers)

- Responsibility for guaranteeing the military security of the state

- Corporate nature, formed by complex procedures and requirements for access to the profession, an explicit system for promotion and appointments, the system of military education, a clear hierarchy and staff organization, esprit and competence of the officer corps.

Huntington further showed that the behavior of the officer within the military structure is guided by a complex system of regulations, norms, customs, and traditions. The officer's professional stance towards society is based on the understanding that his or her expertise may be applied only for purposes that are approved by society through its political agent, the state.

7 Samuel P. Huntington, The Soldier and the State: The Theory and Politics of Civil-Military Relations (Cambridge, MA: Harvard University Press, 1985), 8-18. 


\section{The Profession of Civilian Defense Experts vis-à-vis the Military Officer Corps}

According to Huntington, the duties of the military officer include organizing, equipping, and training the armed forces; planning their activities; and directing their operation in and out of combat. ${ }^{8}$ In the exercise of these duties, the military officer frequently interacts with civilian experts (as well as with politicians). For example, civilians have a clear leadership role in formulating policy, while they play practically no role in commanding the troops. However, in the area of "planning the activities" of the armed forces, and in particular in "organizing and equipping the troops," there is considerable interaction between military and civilian expertise. The contributions of both civilians and military officers are indispensable, and usually complement each other in a sophisticated decision-making framework. The comparison of expert contributions of the two groups is summarized in Table 1.

Table 1: Specific Expertise of Military Officers and Defense Civilians

\begin{tabular}{lcc}
\hline & Military officers & $\begin{array}{c}\text { Civilian defense } \\
\text { experts }\end{array}$ \\
\hline Setting policy goals & - & +++ \\
\hline Organizing and equipping the force & ++ & ++ \\
\hline Planning military activities & ++ & + \\
\hline $\begin{array}{l}\text { Direction of force operations in and out } \\
\text { of combat }\end{array}$ & +++ & - \\
\hline
\end{tabular}

Both civilian and military personnel are responsible to society for the status of the armed forces. However, the military officers are responsible primarily for the adequate, timely, and professional employment of force, its training and readiness, while civilians are mostly concerned with effectiveness and efficiency in the use of limited societal resources. The distinct expertise of the two groups is respectively in management of violence and management of defense institutions. Both groups have a distinct system of access to the profession and promotion, hierarchical rank structure, code of conduct, etc. All these distinctions are summarized in Table 2.

All these distinctions indicate that defense civilians may be seen as a distinct professional group, just like their military counterparts. But how can a professional corps of civilian defense experts be created in a country where it does not exist?

8 Huntington, The Soldier and the State, 11.

9 Or "defense/force planning" in current terms. 
Table 2: Features of the Profession of Civilian Defense Experts vis-à-vis the Military Officer Corps

\begin{tabular}{lll}
\hline & Military officers & Civilian defense experts \\
\hline Expertise & Management of violence & Defense management \\
\hline $\begin{array}{l}\text { Responsibility } \\
\text { to society }\end{array}$ & - For the status of the armed & • For the status of the armed \\
& forces & forces \\
& - For adequate, timely, and pro- & - For effective use of societal \\
& fessional employment of force & resources \\
\hline Corporateness & Access, promotion, hierarchy, & $\begin{array}{l}\text { Access, promotion, hierarchy, } \\
\text { esprit }\end{array}$ \\
& esprit & \\
\hline
\end{tabular}

\section{Towards the Creation of a Civilian Cadre of Defense Experts}

As Chris Donnelly acknowledged a decade ago, it is not important how good theoretically the written norms for democratic civilian control are if there are no competent parliamentarians and civilians in governmental positions who are able to speak on equal footing with the military and understand their justifiable needs. ${ }^{11}$ Also, there is a need not only for civilian experts, but for institutional guarantees that civilians in government, and in the ministry of defense in particular, will be adequately qualified to perform their duties.

The formation of a professional cadre of civilian defense experts is one such guarantee. A sample of measures that would work toward the creation of such a cadre would include:

- Recognition and legal definition of the role of defense civilians

- Establishment of a system of recruitment and selection of civilians for jobs in the defense sector

- Definition of clear career paths, with a system of ranks, promotion, etc., ${ }^{12}$ allowing for the rotation of defense experts among ministries, other executive agencies, parliamentary staff, audit offices, and other related organizations

- Establishment of requirements and opportunities for education and training of defense civilians ${ }^{13}$

10 I have not systematically studied the issues of loyalty, esprit, etc., as they apply to the civilian defense cadre.

11 Chris Donnelly, "Defense Transformation in the New Democracies: A Framework for Tackling the Problem," NATO Review 45:1 (1997): 15-19.

12 The introduction of a "Law on Civil Service/Servants" may contribute to the implementation of this and the previous requirement. 
- Creation of a distinct professional ethos, i.e. through introduction of "codes of conduct" and other means.

An important issue, particularly for post-totalitarian societies, relates to the employment of retiring military officers in civilian positions in defense ministries. The utilization of available experience is important, and often countries experiencing the transition to democracy have no alternative. However, a "civilian cadre" composed largely of former military officers can hardly be considered a professional corps of civilian defense experts.

\section{Modes of Civil-Military Interaction in Defense Ministries}

Civilian defense experts perform important functions in several areas. First, they provide specific expertise that is usually unavailable within the officer corps - for example, in the elaboration of security and defense policies, project management, costing, cost-benefit analysis, etc. Secondly, civilian experts may independently assess proposals made by the senior military leadership and, when necessary, may provide alternative proposals in areas of their expertise. Third, on behalf of a defense minister, civilians may coordinate the design of ministerial guidance of various kinds, the preparation of decision acts, implementation oversight functions, etc.

These functions may be exercised in two distinct modes: control mode and cooperative mode. In the first mode, civilians clearly support the political leaders in the exercise of their oversight functions. They are seen as part of the control mechanism, which often breeds resentment within the officer corps and produces a variety of obstructions. This mode of using civilians is prevalent in defense ministries of Central and Eastern European countries.

The second, cooperative mode is highly preferable. ${ }^{14}$ Ideally, it is based on:

- Goal-oriented interaction between expert civilians and the military, with participation commensurate to the available expertise and specific experience

- An organizational culture that not only tolerates but encourages differences in opinion and approach while promoting cooperative decision making

- Mutual confidence and respect.

13 Preferably through a system of education and qualification courses in which civilians study jointly with their military counterparts. For details, refer to Todor Tagarev, The Role of Military Education in Harmonizing Civil-Military Relations, Final Report, NATO Democratic Institutions Fellowship Program (1997); available at www.nato.int/acad/fellow/95-97/ tagarev.pdf.

For example the reader may refer to Dr. Todor Tagarev and Col. Dobromir Totev, "Civilians and the Military in Defense Planning," in Defense and Security Sector Governance and Reform in South East Europe: Insights and Perspectives, Vol. I, eds. Jan A. Trapans and Philipp H. Fluri (Geneva: Geneva Centre for the Democratic Control of Armed Forces, 2003), 217-30. 
In this mode, civilian experts are readily distinguished from the political 'masters,' while the latter preserve clear supremacy over all significant decisions on the development and the use of the armed forces.

\section{Conclusion}

There is an apparent need to develop a professional corps of defense civilians. Modern leadership and management theories convincingly prove that effective organizations thrive on representative diversity of decision making, and are characterized by a contribution of ideas and opinions from across a wide spectrum. Leaders, both military and civilian, need options - they need to hear debate and criticism, no matter how unwelcome, or how foreign to a hierarchical culture. Therefore, professional civilian experts, working together with their counterparts in uniform, may have a profound impact on the successful transformation of defense establishments in the twenty-first century. 


\section{THE QUARTERLY JOURNAL}

\section{Bibliography}

Donnelly, Chris. "Defense Transformation in the New Democracies: A Framework for Tackling the Problem." NATO Review 45, no. 1 (1997): 15-19.

Huntington, Samuel P.. The Soldier and the State: The Theory and Politics of CivilMilitary Relations. Cambridge, MA: Harvard University Press, 1985.

Nelson, Daniel. "Civilians, The Military and Defense Planning in South East Europe: An Analysis of the Stability Pact Self-Assessment Studies." In Defense and Security Sector Governance and Reform in South East Europe Self-Assessment Studies Regional Perspectives, 125-135. Baden-Baden: Nomos Verlagsgesellschaft, 2004.

Tagarev, Todor, and Dobromir Totev. "Civilians and the Military in Defense Planning." InDefense and Security Sector Governance and Reform in South East Europe: Insights and Perspectives, 217-230. Geneva: Geneva Centre for the Democratic Control of Armed Forces, 2003.

Tagarev, Todor. The Role of Military Education in Harmonizing Civil-Military Relations. NATO Democratic Institutions Fellowship Program, 1997. 